University of Nebraska - Lincoln

DigitalCommons@University of Nebraska - Lincoln

Faculty Publications from the Harold W. Manter Laboratory of Parasitology

6-1988

Rhinebothrium devaneyi n. sp. (Eucestoda: Tetraphyllidea) and Echinocephalus overstreeti Deardorff and Ko, 1983 (Nematoda: Gnathostomatidae) in a Thorny Back Ray, Urogymnus asperrimus, from Enewetak Atoll, with Phylogenetic Analysis of Both Species Groups

\author{
Daniel R. Brooks \\ University of Toronto,dnlbrooks@gmail.com \\ Thomas L. Deardorff \\ United States Food and Drug Administration
}

Follow this and additional works at: https://digitalcommons.unl.edu/parasitologyfacpubs

Part of the Parasitology Commons

Brooks, Daniel R. and Deardorff, Thomas L., "Rhinebothrium devaneyi n. sp. (Eucestoda: Tetraphyllidea) and Echinocephalus overstreeti Deardorff and Ko, 1983 (Nematoda: Gnathostomatidae) in a Thorny Back Ray, Urogymnus asperrimus, from Enewetak Atoll, with Phylogenetic Analysis of Both Species Groups" (1988). Faculty Publications from the Harold W. Manter Laboratory of Parasitology. 240.

https://digitalcommons.unl.edu/parasitologyfacpubs/240

This Article is brought to you for free and open access by the Parasitology, Harold W. Manter Laboratory of at DigitalCommons@University of Nebraska - Lincoln. It has been accepted for inclusion in Faculty Publications from the Harold W. Manter Laboratory of Parasitology by an authorized administrator of DigitalCommons@University of Nebraska - Lincoln. 


\title{
RHINEBOTHRIUM DEVANEYI N. SP. (EUCESTODA: TETRAPHYLLIDEA) AND ECHINOCEPHALUS OVERSTREETI DEARDORFF AND KO, 1983 (NEMATODA: GNATHOSTOMATIDAE) IN A THORNY BACK RAY, UROGYMNUS ASPERRIMUS, FROM ENEWETAK ATOLL, WITH PHYLOGENETIC ANALYSIS OF BOTH SPECIES GROUPS
}

\author{
Daniel R. Brooks and Thomas L. Deardorff \\ Department of Zoology, University of British Columbia, 2075 Westbrook Mall, \\ Vancouver, British Columbia, Canada V6T 2A9, and \\ Fishery Research Branch, United States Food and Drug Administration, Box 158, \\ Dauphin Island, Alabama 36528
}

\begin{abstract}
The new species is a member of an apparently monophyletic group within the genus that includes $R$. flexile, $R$. walga, $R$. himanturi, $R$. burgeri, $R$. euzeti, $R$. hawailensis, $R$. urobatidium, $R$. paratrygoni, $R$. ditesticulum, $R$. tetralobatum, $R$. margaritense, $R$. biorchidum, and $R$. spinicephalum. All of these species have bothridia with medial longitudinal septa, a constriction at mid-bothridium, and, primitively, at least 42 loculi per bothridium and 17-22 testes per proglottid. Of the above, the new species is apparently most closely related to $R$. burgeri, with which it shares an increased number of testes (30-43) per proglottid, a V-shaped ovary, and a muscular genital pore. The new species is distinct by virtue of possessing 94-152 loculi per bothridium-no other known species has more than 78. This is the second report of Echinocephalus overstreeti from a stingray. It represents a new host, $U$. asperrimus, and a new location, Enewetak Atoll. Phylogenetic and biogeographic analysis of each species group suggests an ancient Tethys Sea-circum-Pacific origin and evolution. This supports the hypothesis of ancient Pacific origins for potamotrygonid stingrays.
\end{abstract}

In 1981, the Bernice P. Bishop Museum (BPBM), Honolulu, conducted an expedition to Enewetak Atoll to study marine vertebrates and invertebrates. During this survey, the gastrointestinal tract (specific location not noted) of a thorny back stingray, Urogymnus asperrimus (Bloch and Schneider), was found to contain 8 specimens of a previously undescribed tetraphyllidean cestode and 7 adult nematodes. Worms were removed from the gastrointestinal tract of the captured host by the scientists of the BPBM, placed in formalin, and stored in ethyl alcohol. Subsequently, the cestodes were stained with acetocarmine and mounted in Permount for study as whole mounts. Nematodes were cleared and examined in lactic acid. Average measurements of characters are presented with ranges and sample size $(\mathrm{n}=)$ in parentheses. Measurements are in $\mu \mathrm{m}$ unless stated otherwise. Figures were drawn with the aid of a drawing tube. Scanning electron microscopy was used to verify morphology of scolex.

Received 29 August 1986; revised 7 June 1987; accepted 15 September 1987.

\section{DESCRIPTION \\ Rhinebothrium devaneyi n. sp. \\ (Figs. 1-4)}

General description (based on 8 specimens): Strobila $0.9(0.5-1.2) \mathrm{cm}$ long $(\mathrm{n}=5)$, acraspedote, apolytic, composed of $33(26-39)$ proglottids $(n=5)$. Scolex aspinose, composed of 4 pedicellated, elongate, septate bothridia. Bothridia with margins curled and lobulated, divided longitudinally by median septum, with slight constriction between lobes; total number of loculi per bothridium $128(94-152)(n=8)$ plus terminal loculus at tip of each lobe. Bothridial lobes $1.0(0.9-1.2) \mathrm{mm}$ long by $252(119-320)$ wide $(n=4)$. Pedicels $199(62-$ $288)$ long $(n=7)$. Cephalic peduncle short, 286 (196$445)$ long $(n=5)$. Immature proglottids wider than long. Mature proglottids $0.8(0.5-1.9)$ long by $287(241-$ $356)$ wide $(n=14)$. Genital pore $60 \%(50-66 \%)$ of proglottid length from anterior end $(n=20)$, irregularly alternating.

Male genitalia: Testes $37(30-43)$ in number $(\mathrm{n}=$ $20), 18(14-21)$ poral, $19(15-22)$ aporal $(n=14)$. Cirrus sac elongate, 197 (137-240) long by 91 (65-116) wide $(n=13)$, containing spined eversible cirrus. Genital atrium shallow, genital pore highly muscular.

Female genitalia: Vagina anterior to cirrus sac, sphincter present. Ovary X-shaped in cross section, $\mathrm{V}$-shaped in frontal view; lobes extending anteriorly to posterior margin of cirrus sac; 240 (112-471) long by $93(36-222)$ wide at isthmus $(n=14)$. Vitellaria along lateral margins and extending entire length of proglottid, not in single file, converging toward midline of proglottid at posterior extremity, follicular, $1.0(0.4$ 

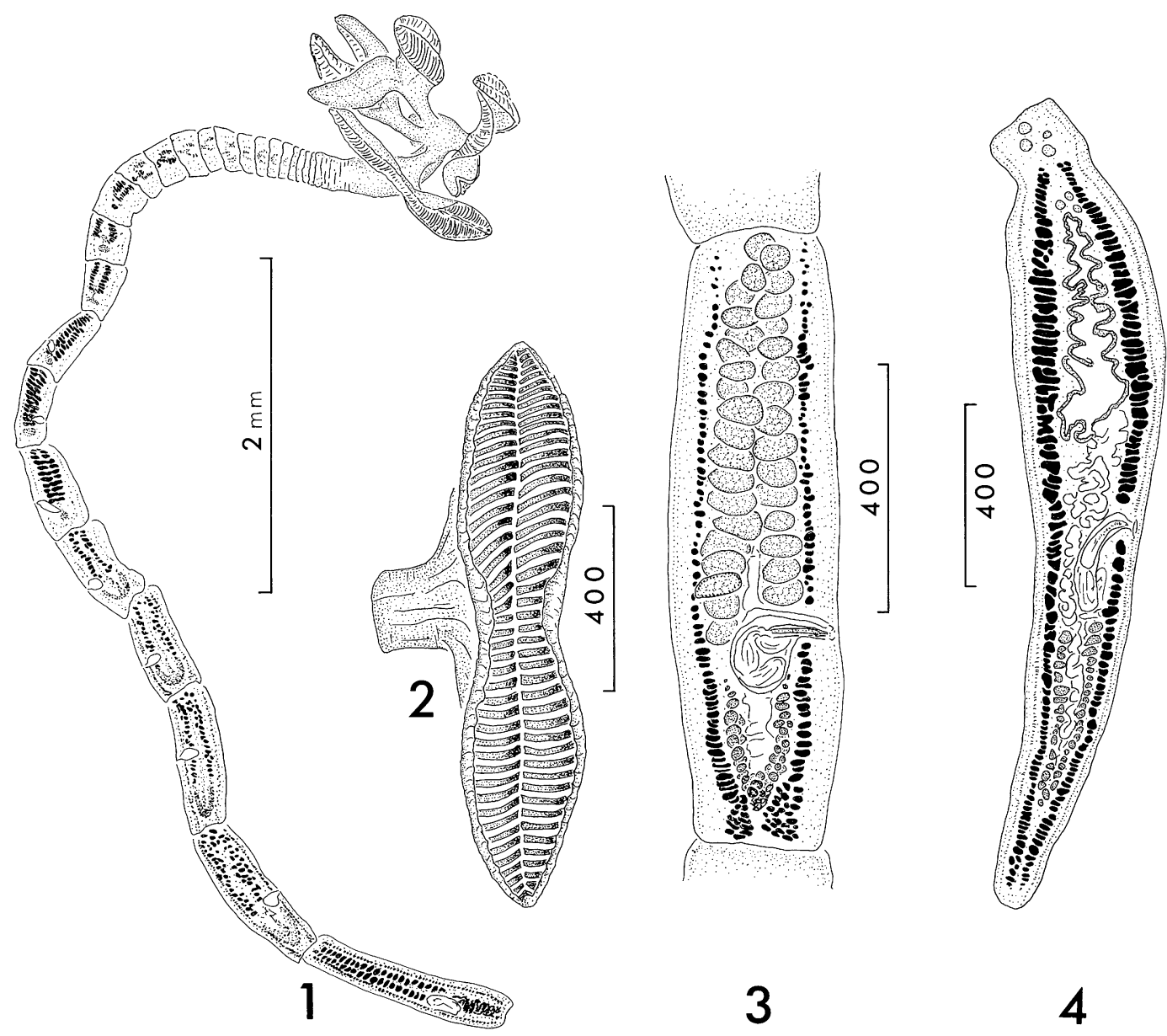

FIgures 1-4. Rhinebothrium devaneyi n. sp. 1. Entire worm. 2. Bothridium (diagrammatic). 3. Mature proglottid. 4. Terminal proglottid.

1.7) $\mathrm{mm}$ long $(\mathrm{n}=16)$; follicles elliptical, $18(11-89)$ in diameter $(\mathrm{n}=30)$. Uterus simple, median, tubular $(n=1)$. Eggs not seen.

\section{TAXONOMIC SUMMARY}

Twenty of the species of Rhinebothrium, including $R$. devaneyi, are characterized by having a median longitudinal septum on the face of each bothridium (6 species of Caulobothrium share this trait as well): $R$. monodi Euzet, 1954; R. baeri Euzet, 1956; R. maccallumi Linton, 1924; R. tumidulum (Rudolphi, 1819) Euzet, 1956; $R$. setiensis Euzet, 1955; R. lintoni Campbell, 1970; $R$. burgeri Baer, 1948; $R$. flexile Linton, $1890 ; R$. himanturi Williams, 1964; $R$. walga (Shipley and Hornell, 1905) Euzet, 1956; R. euzeti Williams, 1958; $R$. hawaiiensis Cornford, 1974; $R$. urobatidium (Young, 1955) Appy and Dailey, 1978; $R$. paratrygoni Rego and Dias, 1976; $R$. ditesticulum Appy and Dailey, 1978; R. margaritense Mayes and Brooks, 1981; $R$. spinicephalum Campbell, 1970; R. tetralobatum Brooks,
1977; R. biorchidum Huber and Schmidt, 1985; and $R$. devaneyi. This group also includes all but 2 of the members of the genus having more than 40 loculi per bothridium. The last 14 species listed above possess bothridia that are constricted in the middle (see Fig. 2 ). Of these, $R$. flexile, $R$. burgeri, and $R$. devaneyi have ovaries that appear V-shaped in frontal view rather than $\mathrm{H}$-shaped, because of the posterior confluence of the ovarian lobes and the presence of an indistinct ovarian isthmus. Rhinebothrium devaneyi most closely resembles $R$. burgeri by having 30-43 testes per proglottid (the rest of the "constricted" species have 1722 or fewer) and by having a muscularized genital pore associated with a shallow genital atrium. The new species differs by having a mean number of 128 loculi per bothridium, more than double that reported for $R$. burgeri $(50)$ and at least 50 more than any other known species ( $R$. euzeti has $78, R$. paratrygoni has $72-76$, and $R$. sp. of Williams [1966] has 76).

Rhinebothrium biorchidum was reported by Huber and Schmidt (1985) to have a V-shaped ovary. We examined the type specimens (USNM Helm. Coll. Nos. 
77889,77890 ) and determined that only 1 proglottid, the terminal segment which they illustrated as figure 4 , had a V-shaped ovary. The ovary in the terminal proglottid of most species belonging to Rhinebothrium, however, appears V-shaped because of extreme attenuation of the proglottid. This is the case with $R$. biorchidum. The ovaries in most proglottids of $R$. biorchidum are $\mathrm{H}$-shaped. The placement of this species in our cladogram reflects this finding.

Specimens deposited: Holotype, USNM Helm. Coll. No. 79815; Paratypes, USNM Helm. Coll. No. 79876, University of Nebraska State Museum No. 20970, BPBM No. 1981.334.

Host: Urogymnus asperrimus (Bloch and Schneider) thorny back ray (Dasyatididae); BPBM cat. No. 27792,

J. E. Randall and D. M. Devaney, 12 July 1981.

Site of infection: Recovered from gastrointestinal tract (?spiral valve).

Locality: Enewetak Atoll, in near shore lagoon.

Etymology: This species is named in honor of the late curator of the Invertebrate Zoology Collection at BPBM, Dr. Dennis M. Devaney.

\section{REMARKS}

There is disagreement about the phylogenetic utility and stability of various traits used to characterize species of Rhinebothrium; nevertheless, all taxonomists studying the group resort to a consistent set of traits in their descriptive work. At present, there is no phylogenetic hypothesis for the group, so disagreements have no databased frame of reference. Phylogenetic systematics (Hennig, 1966; see Brooks, 1985, for a review of methods and uses published in the journal) embodies a reproducible method for analyzing data according to genealogical criteria. The cladogram, or phylogenetic tree, that results from such studies represents the most parsimonious estimate of phylogeny allowed by the data at hand. The robustness of such hypotheses can be tested by adding new data, or by finding novel evolutionary insights implied by the relationships shown on the tree. We have provided a phylogenetic tree for 20 of the species of $R h i$ nebothrium.

The group $R$. flexile $+R$. burgeri $+R$. devaneyi is postulated to be the sister-group of the other 11 species having constricted bothridia. Those 10 are postulated to form a monophyletic group characterized by the possession of relatively long bothridial pedicels (at least half as long as the bothridia). Of this group, $R$. himanturi is postulated to be the sister-species of the other 9 because they all have 11-13 or fewer testes per proglottid, whereas $R$. himanturi has 19-20, similar to $R$. flexile (17-22) and $R$. setiensis (25-35). Of the remaining 9 species, $R$. walga and $R$. hawaiiensis appear to share the unique trait of having longitudinal bands of vitellaria rather than discrete follicles. Rhinebothrium euzeti is distinct by virtue of having 78 loculi per bothridium, but does not share any derived traits with any of the other 8 members of the group. The last 6 species form a group, recognized by Brooks et al. (1981a), characterized by having strongly craspedote proglottids, more than 50 proglottids per strobila, squared proglottids rarely longer than wide, and an average of 8 or fewer testes per proglottid. Brooks et al. (1981a) presented a cladogram for these 6 species $(R$. margaritense Brooks and Mayes, 1980, was listed as $R$. sp.), but considered a low number of bothridial loculi to be the primitive trait for the group. Comparisons with the rest of the species considered herein suggest that 47-56 loculi per bothridium is the plesiomorphic condition. This changes the placement of $R$. ditesticulum but does not alter any of the coevolutionary or biogeographic conclusions drawn by Brooks et al. (1981b), which are discussed later.

The phylogenetic hypothesis for 20 of the species belonging to Rhinebothrium (Fig. 5) and discussed above is based on a suite of 27 anatomical characters presented in the figure legend. We have confirmed these characters for 12 of the species by examination of type material or voucher specimens ( $R$. maccallumi, $R$. devaneyi, $R$. flexile, $R$. hawaiiensis, $R$. lintoni, $R$. urobatidium, $R$. paratrygoni, $R$. margaritense, $R$. ditesticulum, $R$. tetralobatum, $R$. biorchidum, and $R$. spinicephalum. Note: There are more species of Rhinebothrium.) We have not included a character for the true hinged condition because we are unsure, based on original descriptions, which species really have this characteristic.

Figure 5 is the cladogram summarizing the putative phylogenetic relationships discussed above. It is evident that although every described species of Rhinebothrium is reported to have a unique number of testes per proglottid and loculi per bothridia, these characters have been extremely plastic in the course of evolution and are of limited use, by themselves, in phylogenetic analysis. However, we would note that the members of Rhinebothrium having constricted bothridia, plus $R$. lintoni and $R$. setiensis which do not, comprise 13 of the 15 known species exhibiting 40 or more loculi per bothridium. In addition, the group of "constricted" species having long bothridial pedicels comprises 10 of the 15 known species with fewer than 15 testes per proglottid. 


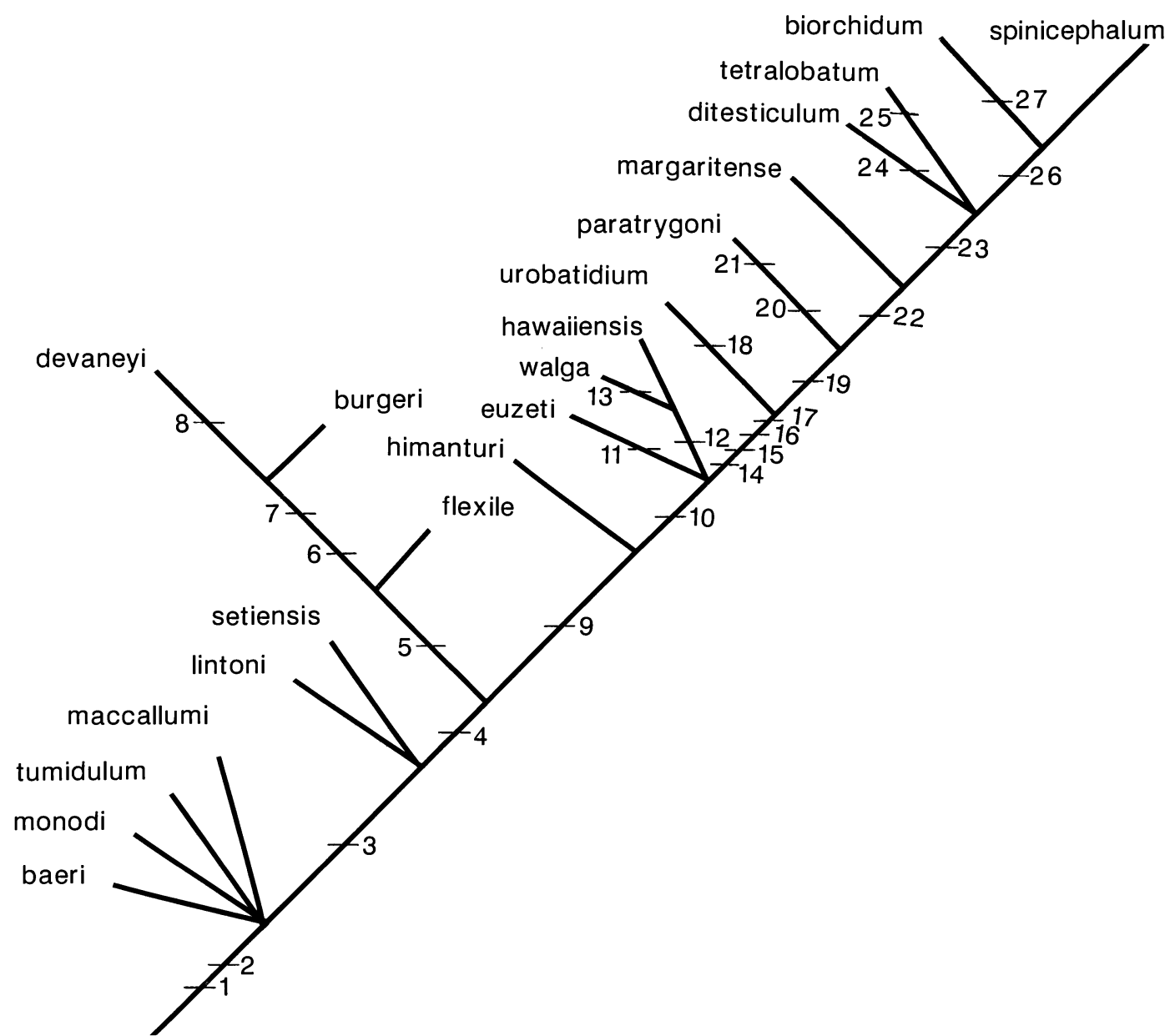

FIGURE 5. Cladogram depicting phylogenetic relationships of Rhinebothrium species having bothridial constrictions. Numbers accompanying slash marks on tree indicate synapomorphic traits as follows: (1) median septum in bothridia; (2) 17-22 testes per proglottid; (3) 42-56 loculi per bothridium; (4) constricted bothridia; (5) V-shaped ovaries; (6) muscular genital pore; (7) 30-43 testes per proglottid; (8) 96-154 loculi per bothridium; (9) bothridial pedicels $1 / 2$ bothridial length; (10) 11-13 testes per proglottid; (11) 78 loculi per bothridium; (12) compact vitelline bands; (13) 4-6 testes per proglottid; (14) craspedote proglottids; (15) more than 50 proglottids per strobila; (16) square proglottids; (17) 6-12 $(\bar{x}=8)$ testes per proglottid; (18) 38-42 loculi per bothridium; (19) 4-8 $(\bar{x}=5)$ testes per proglottid; (20) long cephalic peduncle; (21) 72-76 loculi per bothridium; (22) 3-6 $(\bar{x}=4)$ testes per proglottid; $(23) 2(\bar{x}=2)$ testes per proglottid; (24) long cephalic peduncle; $(25)$ fragmented ovary; (26) 32-34 loculi per bothridium; (27) 22-30 loculi per bothridium. Not all characters for bottom 6 species listed.

It is evident from Figure 5 that while available data support a particular set of phylogenetic relationships, additional characters are needed to provide a stronger case and better resolution. Undoubtedly some postulated relationships will change as new data become available. However, the phylogenetic tree presented herein will provide a stable framework within which such changes can be made effectively. We may also evaluate the robustness of the tree presented in
Figure 5 by reference to questions of evolutionary history and biogeography.

Brooks et al. (1981b) discussed the evolutionary history of the parasites inhabiting neotropical freshwater stingrays (family Potamotrygonidae). Their study suggested that the potamotrygonids were derived from a Pacific ancestor over 100 million years ago. One prediction of this hypothesis is that other neotropical species with marine affinities should have Pacific marine rel- 


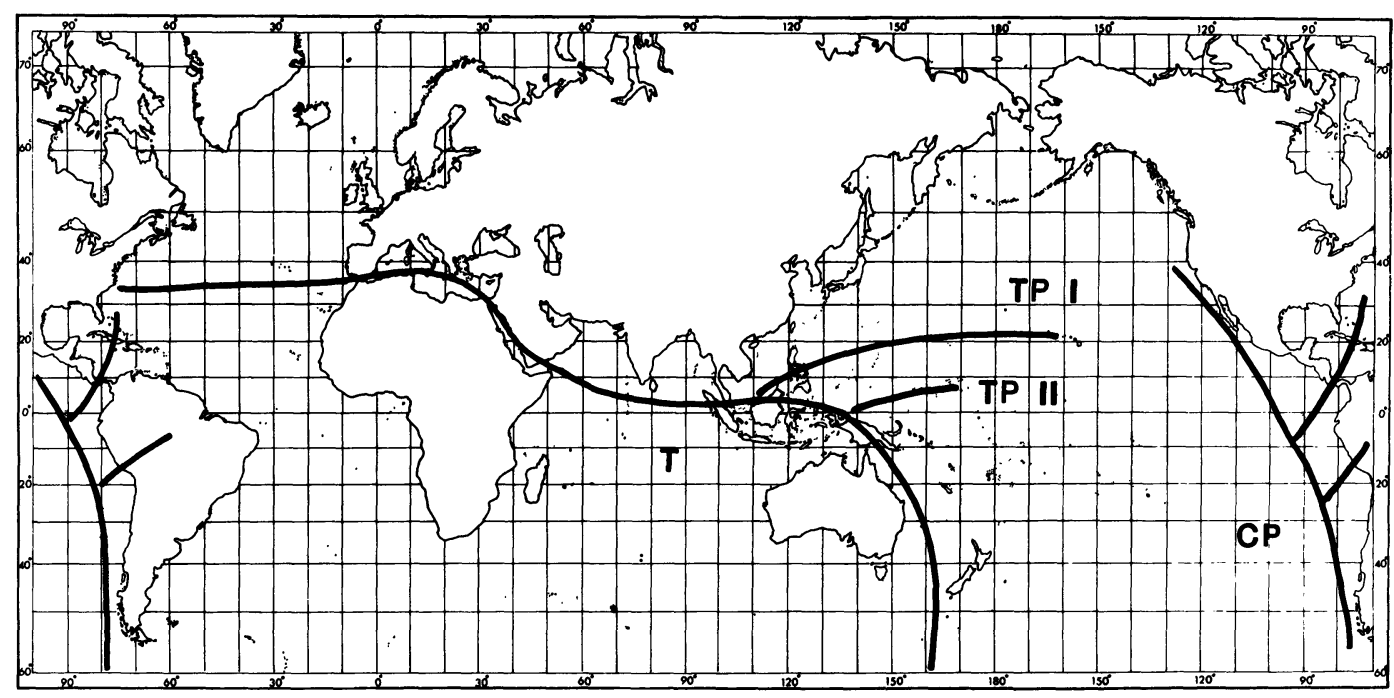

FIGURE 6. Biogeographic pattern of Rhinebothrium species having bothridial constrictions. Tethyan $(=\mathrm{T})$ (Atlantic-Mediterranean-Indo-Malaysian): $R$. baeri, $R$. monodi, $R$. tumidulum, $R$. maccallumi, $R$. lintoni, $R$. setiensis, $R$. flexile, $R$. burgeri, $R$. euzeti, $R$. walga. Trans-Pacific I (=TP I) (Tethys-Hawaii): $R$. hawaiiensis. Trans-Pacific II (=TP II) (Tethys-Enewetak): $R$. devaneyi. Circum-Pacific (=CP): $R$. himanturi (Australia), $R$. urobatidium, $R$. ditesticulum (eastern Pacific); $R$. paratrygoni (South American freshwater); $R$. margaritense, $R$. tetralobatum, $R$. biorchidum, R. spinicephalum (Caribbean and west Atlantic).

atives. Nelson (1984) has shown a similar pattern for neotropical freshwater anchovies and their marine relatives. Another prediction presented by Brooks et al. (1981b) is that the relatively more plesiomorphic species in the parasite groups having members inhabiting potamotrygonids should have circum-Pacific distributions, indicating a biogeographic history stretching back to before the breakup of Gondwana. Furthermore, any members of such parasite groups that have trans-Pacific distributions should not be closely related to the species occurring in potamotrygonids.

Figure 6 shows the biogeographic pattern for Rhinebothrium species having bothridial constrictions. This is clearly a Pacific group, with only 3 Atlantic endemics, 2 of which occur in the Caribbean Sea. The species occurring in potamotrygonids ( $R$. paratrygoni) is most closely related to circum-Pacific species, whereas $R$. hawaiiensis and $R$. devaneyi, the 2 trans-Pacific species, are most closely related to Indo-Malayan species. Thus, the biogeographic affinities of the 20 species of Rhinebothrium discussed herein support one of the predictions made by Brooks et al. (1981b). We stated above that the robustness of phylogenetic trees is increased by increasing the number of characters used. Biogeographic analyses are made more robust by demonstrating that more than one group of organisms show the same historical pattern of geographical distribution. We will now consider some of the members of the nematode genus Echinocephalus, one of which inhabits $U$. asperrimus from Enewetak.

\section{Echinocephalus overstreeti Deardorff and Ko, 1983}

Deardorff and Ko (1983) described the gnathostome nematode Echinocephalus overstreeti in Taeniura melanopilos from the Marquesas Islands. In addition to a new report of $E$. overstreet $i$ in $U$. asperrimus, our findings also extend the geographic range of the species. Specimens of $E$. overstreet $i$ in $U$. asperrimus from Enewetak are deposited in the BPBM as No. 1981.334.

Deardorff et al. (1980) presented a preliminary cladogram for part of Echinocephalus in conjunction with the description of $E$. daileyi from freshwater stingrays. Subsequently, Deardorff and Ko (1983) described $E$. overstreeti and discussed possible modifications in the cladogram presented by Deardorff et al. (1980). More recently, Beveridge (1985) redescribed E. uncinatus and E. spinosissimus and corrected previous reports of some morphological characters. Based on these subsequent studies and the specimens reported herein, we present an updated cladogram (Fig. 


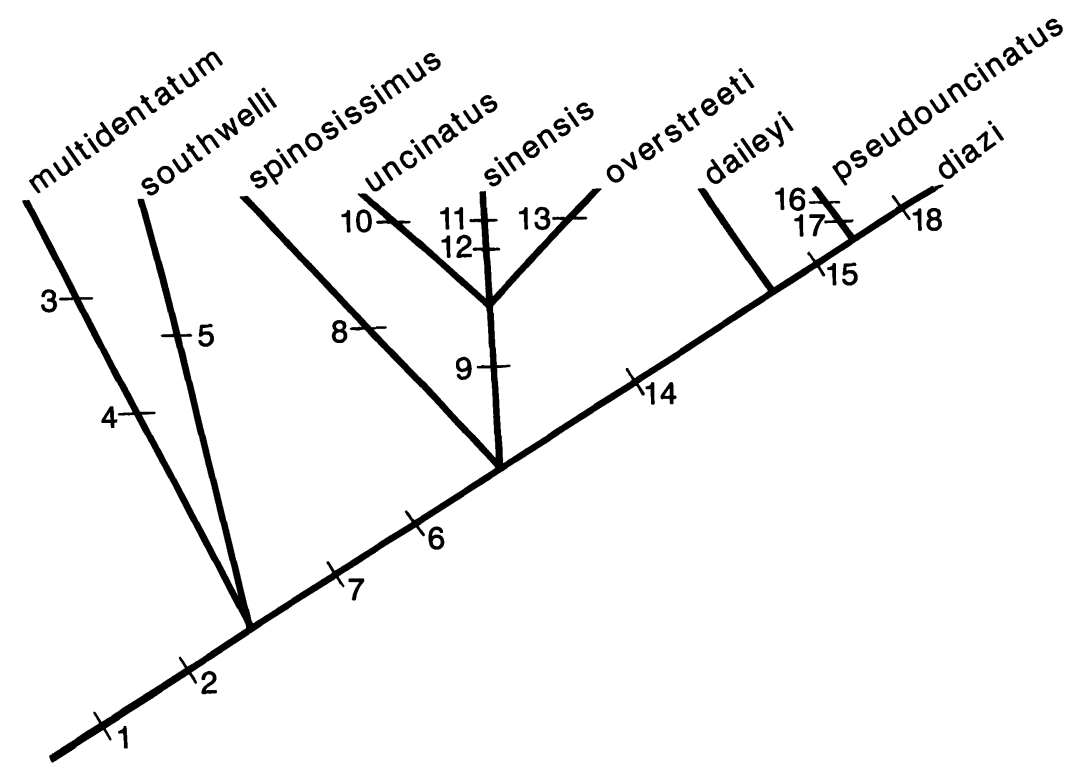

FIGURE 7. Cladogram, modified from Deardorff et al. (1980), depicting phylogenetic relationships of Echinocephalus species. Numbers accompanying slash marks on tree indicate synapomorphic traits as follows: (1) 5 pairs of postanal papillae; (2) 3 pairs of preanal papillae; (3) 15-18 rows of cephalic spines; (4) 4 pairs of postanal papillae; (5) 11-13 rows of cephalic spines; (6) 30-45 rows of cephalic spines; (7) gubernaculum present; (8) 5 pairs of postanal papillae in cluster; (9) ventral rugose areas surrounding male cloaca; (10) 5 pairs of postanal papillae in cluster; (11) 2 pairs of preanal papillae; (12) 26-29 rows of cephalic spines; (13) 3 pairs of postanal and 1 pair of adanal papillae; (14) 6 pairs of postanal papillae; (15) 25-27 rows of cephalic spines; (16) 3 pairs of postanal papillae; (17) 16-21 rows of cephalic spines; (18) 2 pairs of preanal papillae.

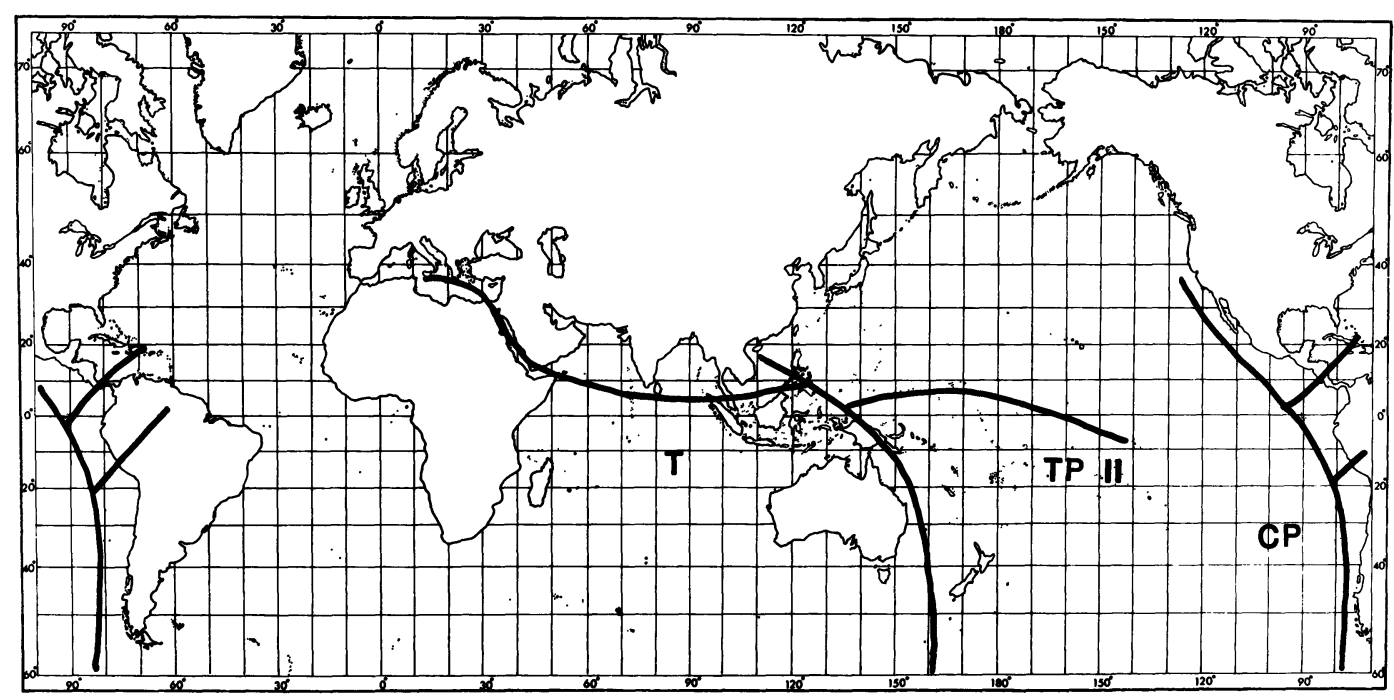

FIGURE 8. Biogeographic pattern of Echinocephalus species. Tethyan $(=\mathrm{T})$ (Mediterranean-Indo-Malaysian): E. multidentatus, E. southwelli, E. mobulae, E. uncinatus. Trans-Pacific II (=TP II) (Tethys-Hong KongEnewetak/Marquesas): $E$. sinensis, E. overstreeti. Circum-Pacific (=CP): E. daileyi (South American freshwater), E. pseuduncinatus (Eastern Pacific), E. diazi (Caribbean). 
7) based on a suite of 18 anatomical characters listed in the figure legend. The present phylogenetic hypothesis differs from that of Deardorff et al. (1980) in 3 ways. First, E. overstreeti has been included and is postulated to be a sisterspecies of $E$. sinensis (see also Deardorff and Ko, 1983 ). Second, $E$. spinosissimus is included as a valid species. And third, both $E$. uncinatus and $E$. spinosissimus, by virtue of possessing a gubernaculum in males, belong in a clade containing all species except $E$. multidentatum and $E$. southwelli. The relative relationships of the $E$. sinensis group and the E. daileyi-E. pseudouncinatus-E. diazi clade remain the same as postulated by Deardorff et al. (1980).

Phylogenetic trees can be used to predict previously undetected biological similarities in closely related species (Brooks, 1985). The larval stages of $E$. sinensis Ko, 1975, have been shown to be capable of penetrating the gastrointestinal tract and undergoing random visceral migrations in a variety of mammals (Ko et al., 1975; Ko, 1976). This species, therefore, may represent a human health risk to consumers of the raw oyster, Crassostrea gigas, in Hong Kong, Southern China, where the worm's life cycle is known to exist. To date, no other species of Echinocephalus has been tested for invasiveness. However, as Figure 7 shows, E. sinensis is most closely related to $E$. overstreeti. Perhaps the invasive potential of $E$. overstreeti is also similar to that of $E$. sinensis. The third-stage larvae of $E$. overstreeti are found in an edible mollusc (unpubl. obs.).

Figure 8 shows the biogeographic pattern indicated by that cladogram. Note that $E$. overstreeti, a trans-Pacific species, is most closely related to $E$. daileyi, the species found in potamotrygonids. Thus, for 2 parasite groups investigated so far, the predictions by Brooks et al. (1981b) have been corroborated. This strengthens the hypothesis of ancient Pacific origins for potamotrygonid stingrays.

\section{ACKNOWLEDGMENTS}

We acknowledge the late Dr. Dennis M. Devaney, at the BPBM, Honolulu, for loaning of specimens and Dr. John E. Randall, also at the BPBM, for providing the host identification. This study was partially funded by operating grant A7696 from the Natural Sciences and Engineering Research Council of Canada to D.R.B.

\section{LITERATURE CITED}

BEVERIDGE, I. 1985. A redescription of Echinocephalus uncinatus Molin, 1858 (Nematoda, Gnathostomatoidea) from European rays, Dasyatis pastinaca (Linnaeus, 1758). Bulletin de la Museum National d'Histoire Naturelle, Paris 7: 781-790.

BRooks, D. R. 1985. Phylogenetics and the future of helminth systematics. Journal of Parasitology 71: 719-727.

$\longrightarrow$ M. A. MAYes, AND T. B. Thorsen. 1981a. Systematic review of cestodes infecting freshwater stingrays (Chondrichthyes: Potamotrygonidae) including four new species from Venezuela. Proceedings of the Helminthological Society of Washington 48: 43-64.

$\longrightarrow$, T. B. Thorsen, AND M. A. MAYes. $1981 \mathrm{~b}$. Freshwater stingrays (Potamotrygonidae) and their helminth parasites: Testing hypotheses of evolution and coevolution. In Advances in cladistics: Proceedings of the first meeting of the Willi Hennig Society, V. A. Funk and D. R. Brooks (eds.). New York Botanical Garden, New York, pp. 147-175.

DEARDORFF, T. L., D. R. BROOKS, AND T. B. THORSEN. 1980. Two species of Echinocephalus (Nematoda: Gnathostomidae) from neotropical stingrays with comments on E. diazi. Journal of Parasitology 67: 433-439.

— AND R. C. Ko. 1983. Echinocephalus overstreetisp. n. (Nematoda: Gnathostomatidae) in the stingray, Taeniura melanopilos Bleeker, from the Marquesas Islands, with comments on E. sinensis Ko. 1975. Proceedings of the Helminthological Society of Washington 50: 285-293.

HenNig, W. 1966. Phylogenetic systematics. University of Illinois Press, Urbana.

Huber, P. M., AND G. D. Schmidt. 1985. Rhinebothrium biorchidum n. sp., a tetraphyllidean cestode from a yellow-spotted stingray, Urolophus jamaicensis, in Jamaica. Journal of Parasitology 71: 1-3.

Ko, R. C. 1976. Experimental infection of mammals with larval Echinocephalus sinensis (Nematoda: Gnathostomatidae) from oysters (Crassostrea gigas). Canadian Journal of Zoology 54: 597-609.

, B. MORTON, AND P. S. WONG. 1975. Prevalence and histopathology of Echinocephalus sinensis (Nematoda: Gnathostomatidae) in natural and experimental hosts. Canadian Journal of Zoology 53: 550-559.

Nelson, G. 1984. Identity of the anchovey Hildebrandichthys setiger with notes on relationships and biogeography of the genera Engraulis and $\mathrm{Ce}$ tengraulis. Copeia 1984: 422-427.

Williams, H. H. 1966. The ecology, functional morphology and taxonomy of Echeneibothrium Beneden, 1849 (Cestoda: Tetraphyllidea), and revision of the genus and comments on Discobothrium Beneden, 1870, Pseudanthobothrium, Baer, 1956 and Phormobothrium, Alexander, 1963. Parasitology 56: 227-285. 